\title{
A gyógyszer indukálta vérzékeny betegek fogorvosi, szájsebészeti ellátása: a 2015-ös hazai szakmai ajánlás alkalmazása és értélkelése
}

\author{
Lukács Dénes dr. ${ }^{1}$ - Stáczer Nóra dr. ${ }^{1}$ - Vajta László dr. ${ }^{1}$ \\ Olasz Lajos dr. ${ }^{1}$ - Joób-Fancsaly Árpád dr. ${ }^{2}$ - Szalma József dr. ${ }^{1}$ \\ ${ }^{1}$ Pécsi Tudományegyetem, Fogorvostudományi Kar, Klinikai Központ, Arc-, Állcsont- és Szájsebészeti Tanszék, \\ Pécs \\ ${ }^{2}$ Semmelweis Egyetem, Fogorvostudományi Kar, Arc-, Állcsont-, Szájsebészeti és Fogászati Klinika, Budapest
}

Bevezetés: A Magyar Arc-, Állcsont- és Szájsebészeti Társaság és a Magyar Fogorvosok Implantológiai Társasága által 2015-ben elfogadásra került „A gyógyszer indukálta vérzékeny betegek fogorvosi ellátása” szakmai ajánlás. Célkitu”zés: A szerzók célja volt az ajánlásban leírt lokális vérzéscsillapítási módszerek hatékonyságának, megbízhatóságának ellenőrzése. Módszer: Az orális antithromboticus kezelésben részesülő betegeiknél vizsgálták a fogorvosi, szájsebészeti ellátásukat követő utóvérzések előfordulását, retrospektív módon. Eredmények: 263, vérzéssel járó beavatkozás történt (186 betegnél), amelyből 138 K-vitamin-antagonista, 97 thrombocytaaggregáció-gátló és 6, úgynevezett új típusú orális antikoaguláns kezelésben részesülő betegeknél. Összesen $6(2,3 \%)$ esetben tapasztaltak utóvérzést az egyórás kontrollnál, míg ügyeletbe 1 beteg jött vissza utóvérzés miatt (0,5\%). Ezzel szemben 86-an jelentkeztek ügyeletükön, akiknél az ajánlást nem vették figyelembe, közülük K-vitamin-antagonista gyógyszert szedett 3 beteg, alacsony molekulasúlyú heparinkezelésben részesült 24 beteg, thrombocytaaggregáció-gátló szert szedett 30 beteg és új típusú orális antikoaguláns kezelésben részesült 1 beteg. Következtetések: A hazai szakmai ajánlás az ambuláns gyakorlatban biztonságosan alkalmazható az antithromboticus terápiában részesülő páciensek vérzéssel járó fogorvosi/szájsebészeti beavatkozásakor, habár a körzetes fogorvos ellátók sok esetben nincsenek ilyen jellegű ellátásra felkészülve. Orv. Hetil., 2016, 157(43), 1722-1728.

Kulcsszavak: antithromboticus kezelés, K-vitamin-antagonista, thrombocytaaggregáció-gátló, új típusú orális antikoaguláns, utóvérzés, fogorvosi-szájsebészeti ellátás

\section{Dental and oral surgical treatment of medication-induced bleeding patients: Audit of the national guideline in Hungary}

Introduction: In 2015 a new Hungarian guideline was published regarding dental treatment and management of anticoagulated patients in agreement of the Hungarian Association of Oral and Maxillofacial Surgeons and the Dental Implantology Association of Hungarian Dentists. Aim: The aim of the authors was to evaluate the efficiency and safety of local hemostatic measures recommended by the guideline in anticoagulated patients. Method: In these patients, postoperative bleeding episodes were examined after dental and oral surgical treatments, retrospectively. Results: Overall 263 bleeding risk cases were treated; 138 patients with vitamin K antagonists, 97 patients with antiplatelet therapy and 6 patients with novel oral anticoagulants. Six patients $(2.3 \%)$ had minor postoperative bleeding after the "one hour control", while one patient needed a night duty support $(0.5 \%)$. In contrast, 86 patients who were treated in rural practices neglecting the guideline attended the night duty with postoperative bleeding ( 3 patients treated with vitamin $\mathrm{K}$ antagonists, 24 patients taking low molecular weight heparin, 30 patients receiving antiplatelet therapy and one patient on novel oral anticoagulant therapy. Conclusions: The Hungarian guideline can be applied safely, without increasing the risk of postoperative bleeding, however, rural dental practices are frequently unprepared for these treatments. 
Keywords: antithrombotic treatment, anticoagulation, vitamin K antagonist, anti-platelet therapy, novel oral anticoagulants, dental-, oral surgical treatment

Lukács, D., Stáczer, N., Vajta, L., Olasz, L., Joób-Fancsaly, Á., Szalma, J. [Dental and oral surgical treatment of medication-induced bleeding patients: Audit of the national guideline in Hungary]. Orv. hetil., 2016, 157(43), $1722-1728$.

(Beérkezett: 2016. július 16.; elfogadva: 2016. augusztus 10.)

\section{Rövidítések}

INR $=$ (International Normalized Ratio) protrombinido", Nemzetközi Normalizált Ráta; LMWH = (low molecular weight heparin) alacsony molekulasúlyú heparin; NOAC = (novel oral anticoagulant) új típusú orális antikoaguláns; TAG = thrombocytaaggregáció-gátló; VKA = K-vitamin-antagonista

Az utóbbi évtizedekben a fogorvosi és szájsebészeti praxisokban egyre több olyan beteggel találkozunk, akik valamilyen véralvadásgátló gyógyszeres kezelésben részesülnek. Ennek fó oka, hogy hazánkban a morbiditási és mortalitási statisztikák első helyén a thrombosisok különböző formái állnak [1]. Az összes halálozás több mint ötven százalékában szerepet játszik a thromboembolia [1].

$\mathrm{Az}$ antithromboticus terápiában részesülő betegek 3 fó csoportját látjuk a fogorvosi, szájsebészeti praxisban: 1. thrombocytaaggregáció-gátló (TAG) terápiában részesülő, 2. K-vitamin-antagonista (VKA) kezelésben részesülő (például acenokumarol, phenokumarol), 3. az úgynevezett új típusú orális antikoagulánsokat szedő (az angol NOAC, novel anticoagulants szóból) betegek [2$5]$. Ezen terápiák bármelyikében részesülő betegeknél a vérzéssel járó fogorvosi/szájsebészeti beavatkozások elvégzésére sokáig nem volt egységes hazai ajánlás. Az egyik általánosan alkalmazott eljárás az úgynevezett szubsztitúciós terápia volt, ahol a kumarinszármazékokat szedő betegek 1,87-os INR-érték felett (egyéb helyeken a gyakorlatban 1,5 felett) alacsony molekulasúlyú heparinra (low molecular weight heparin - LMWH) való átállítását végezték (úgynevezett „bridging” terápia). Másik gyakran tapasztalt út volt a szedett gyógyszer adagjának csökkentése, illetve teljes elhagyása, sokszor körzetes fogorvosi utasításra és a laborvizsgálatok mellőzésével. Mindhárom esetben kisebb-nagyobb mértékben megnövekszik a thromboemboliás szövődmények kockázata [6].

Thrombocytaaggregáció-gátló kezelésben részesülő betegeknél nagyon vegyes képet láttunk. Voltak kollégák, akik a TAG-szer elhagyását kérték néhány napra és utána végezték el a beavatkozást. Találkoztunk olyan esetekkel is, akiknél a TAG-terápia felfüggesztését és LMWH-ra való átállítást javasolták és voltak, akik a kezelés felfüggesztése nélkül végezték az ellátást. Nehézséget okoz általában az is, hogy a fogorvosi diplomával járó jogosultság korlátai miatt (támogatottgyógyszer-felírás hiánya, átállítás monitorozása stb.) gyakran az általános orvosi diszciplínákkal történő együttműködés szükséges. Ez megnöveli az ellátás idejét és sokszor felesleges betegutakat gerjeszt.

2008-ban a Fogorvosi Szemlében megjelent közlemény jó útmutató volt a vérzékeny betegek ellátásával kapcsolatban, amely - főként külföldi tudományos folyóiratokban megjelent cikkekre hivatkozva - tartalmazott algoritmusszerú leírást a veleszületett, illetve szerzett vérzékenységben szenvedő betegek vérzéssel járó beavatkozásainak ellátására [1].

2015-ben a Magyar Arc-, Állcsont- és Szájsebészeti Társaság és a Magyar Fogorvosok Implantológiai Társasága által elfogadásra került „A gyógyszer indukálta vérzékeny betegek fogorvosi ellátása” szakmai ajánlás [7]. Az ajánlás létrejöttével kapcsolatban kiemelendő, hogy a thromboemboliás szövődmények kivédése miatt jött létre elsődlegesen. Irodalmi adatok alapján a thromboemboliás szövődmények a gyógyszerelések megváltoztatásával (például: kumarinok átállítása alacsony molekulasúlyú heparinra) szignifikánsan gyakoribbak $(0,8 \%$, amelyből $0,2 \%$ letális!), mint átállítás nélkül (0\%). Ugyanakkor az intézeti ellátást igénylő posztoperatív vérzésveszély mindkét esetben hasonló $(0,5-0,6 \%)$ [6].

Mivel az ajánlás főként külföldi vizsgálatok és szakmai protokollok alapján készült, célunk volt, hogy saját betegeink körében, hazai környezetben is ellenőrizzük az ajánlás alapján ellátott betegeink körében előforduló utóvérzéseket.

\section{Módszer}

A tanulmányban retrospektív módon azokat a betegeinket vizsgáltuk, akik a PTE Klinikai Központ, Arc-, Állcsont- és Szájsebészet dentoalveolaris szájsebészeti ambulanciáján 2014. november és 2016. május közötti időszakban vérzéssel járó fogorvosi beavatkozáson estek át és a következő három orális antithromboticus kezelés egyikében részesültek: TAG, VKA, illetve NOAC. A már fent hivatkozott szakmai ajánlás alapján jártunk el, amely szerint: „Nem ajánlott felfüggeszteni az ún. "single" (aspirin v. clopidogrel v. ticlopidine) és az ún. "duál« (általában aspirin és clopidogrel együtt) TAG kezeléseket sem. Nem ajánlott felfüggeszteni a VKA (bydroxikumarin, acenokumarin, phenprocoumon) kezelést, ha az INR (protrombinido", Nemzetközi Normalizált Ráta) $\leq 3,5$. 
Nem ajánlott felfüggeszteni a NOAC ("xaban"-ok, dabigatran) kezelést" [7].

Feljegyeztük az ellátott betegeknél a szükséges és megtörtént fogorvosi/szájsebészeti beavatkozásokat, illetve az esetleges utóvérzést minor (sebrevízió és resutura nem szükséges, tanácsadás elégséges vagy minimális beavatkozás szükségeltetik, mint tranexámsavas öblögetés, gézkompresszió), major (lokális érzéstelenítésben lokális sebrevízió, nagyméretû koagulumeltávolítás, újabb suturabehelyezések és szövetragasztás) és osztályos felvételt indokoló (rossz, legyengült általános állapot, transzfúziós ellátás szükségessége) csoportba osztottuk.

A lokális sebellátás és az otthoni utókezelés tanácsadásakor szintén az ajánlás szerint jártunk el, amely szerint: „A fogorvosi kezelés során három fognál többet ne távolitsunk el egyszerre! Törekedni kell a trauma minimalizálására és javasolt egy kvadránsra lokalizálni a beavatkozást. Lehetöleg felszivódó suturával primeren zárjunk minden extrakciós sebet, kollagén v. oxidált cellulóz szivacsok felbasználásával. Beavatkozás után 15-30 percig javasolt a mütéti terület kompressziója gézlapok segitségével, valamint különösen ajánlott a tranexámsavas öblögetés [5\%-os oldattal, ami hazánkban 1 darab 5 ml-es Exacy ${ }^{\circledR}$ (SanofiAventis, Mo.) ampulla fiziológiás $5 \mathrm{ml}$ sóoldattal $10 \mathrm{ml}$ mennyiségre higitva] 1-2 napig legalább, de akár I hétig is; napi 4-szer, alkalmanként 2 percig a szájüregben tartva. A posztoperatín vérzést legalább I órán keresztül kontrollálni javasolt. A non-szteroid és ASA típusú fájdalomcsillapitók helyett célszerübb paracetamol és amidazophen vagy codein hatóanyagú gyógyszerek rendelése" [7].

Vizsgálatunk kiterjedt továbbá az ezen időszakban az ügyeleti ellátásban posztoperatív vérzéses panaszokkal jelentkező betegek ellátási adataira is, különös tekintettel az utóvérzés etiológiájában a lokális és szisztémás okokra, illetve a szükséges vérzéscsillapítási módszerekre (minor vs. major vs. osztályos felvétel).

\section{Eredmények}

Összesen 186 páciens (87 nő, 99 férfi, átlagéletkor $67,7 \pm 23,2$ év) kezelése történt ambulanciánkon. Közülük 98 részesült VKA-kezelésben ( 16 betegnél TAG-terápiával kiegészítve), átlag-INR-értékük 2,62 volt. További hat páciens volt NOAC-szedő, míg 8 beteg LMWH-terápiában, 44 úgynevezett „egyszeres” és 12 pedig úgynevezett „kettős” TAG-kezelésben részesült. 18 páciensnél ezen időszakban nem gyógyszerszedés okozta a vérzékenységet (például: ismert haemophilia, thrombocytopenia, májcirrózis stb.) (1. ábra). Összesen 263 fogorvosi-szájsebészeti beavatkozást végeztünk el, amelynek részletezése az 1 . táblázatban látható.

A szakmai ajánlás alapján ellátott fenti betegcsoportban 6 páciensnél $(6 / 186=3,2 \%)$ és összesen 6 esetben $(6 / 263=2,3 \%)$ volt szükség ismételt tranexámsavas öblögetésre és gézkompresszióra az egyórás megfigyelés után (minor utóvérzés). A 6 páciensből hárman a VKA-

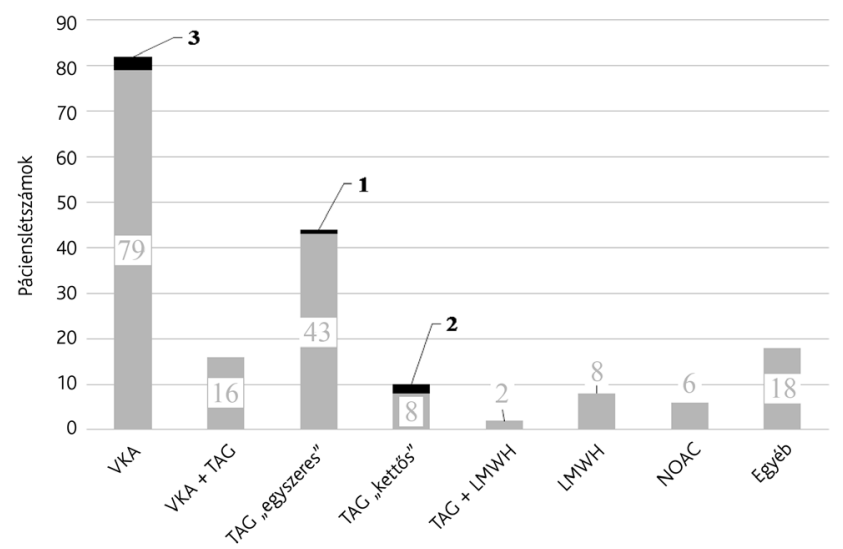

1. ábra

A szakmai ajánlás alapján tanszékünk által ellátott páciensek megoszlása a vérzékenységet okozó gyógyszeres terápia függvényében, ahol a fekete számok és sávok az egy órán túli utóvér zéses eseteket jelölik

LMWH = alacsony molekulasúlyú heparin; NOAC = új típusú orális antikoaguláns; TAG = thrombocytaaggregáció-gátlás; TAG „egyszeres” = egyszeres thrombocytaaggregáció-gátlás; TAG "kettős” = kettős thrombocytaaggregáció-gátlás; VKA = K-vitamin-antagonista

1. táblázat $\mid$ A fogorvosi, szájsebészeti beavatkozások megoszlása betegcsoportunkban

\begin{tabular}{lrc}
\hline Rutin fogeltávolítás, fogóval & 208 & $79,1 \%$ \\
Mútéti fog-, illetve gyökéreltávolítás & 16 & $6,1 \%$ \\
Alveolus korrekciója & 12 & $4,6 \%$ \\
Lágyrész-excízió & 10 & $3,8 \%$ \\
(haemangioma, fibroma, mucokele) & & \\
Alveolitis & 8 & $3,0 \%$ \\
Próba excízió & 5 & $1,9 \%$ \\
Dentális implantáció & 4 & $1,5 \%$ \\
\hline Összesen & 263 & $100,0 \%$ \\
\hline
\end{tabular}

csoportból $(3 / 98=3 \%)$, egy az egyszeres TAG $(1 / 44=$ $2,3 \%)$ és két páciens a kétszeres TAG $(2 / 10=20 \%)$ csoportból került ki (1. ábra). A protokoll alapján általunk ellátott betegcsoportból a munkaidő utáni ügyeleti ellátásunkra mindösszesen egy páciensünk jött vissza $(1 / 186$ $=0,5 \%$ ), akinél szintén minor utóvérzés fordult elő, amelyet tranexámsavas öblögetéssel és gézkompresszióval orvosolni tudtunk.

Ügyeleti ellátásunkon összesen 86 - napközben más fogorvosi praxisban ellátott - páciens jelentkezett utóvérzéssel ezen időszakban (2. ábra). Három esetben VKA gyógyszert szedő betegről (átállítás nélküli ellátás után) (átlag-INR: 3,6), 24 esetben LMWH-ra átállított páciensről, 22 esetben TAG-szert szedő betegrôl volt szó, 8 páciens kettős TAG-ellátásban részesült, 1 beteg kapott NOAC-kezelést, és 28 esetben nem volt gyógyszerszedés, illetve ismert szisztémás ok az utóvérzés hátterében (2. ábra). Az ügyeleti utóvérzések kisebb része 


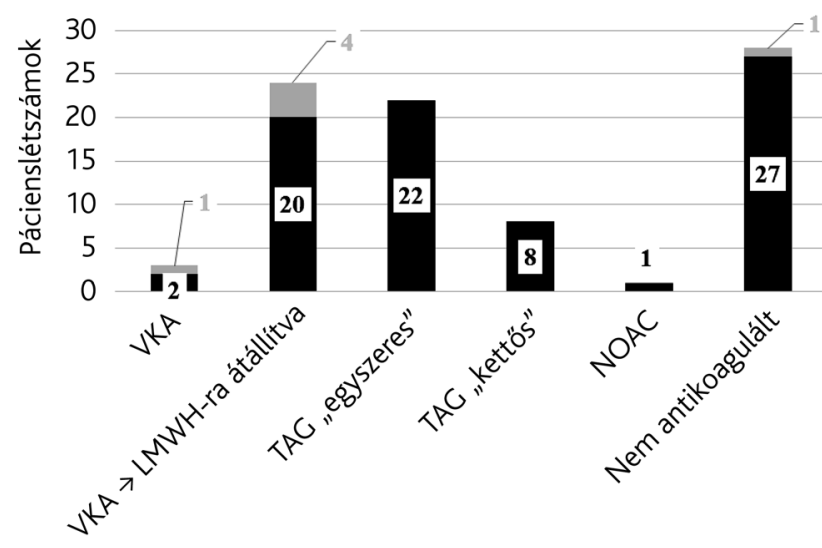

2. ábra

Az ambuláns szakrendelésünkön és ügyeleti ellátásunkon utóvérzéssel jelentkező, külsős praxisokban ellátott betegek megoszlása. A szürke sávok és számok az osztályos felvételt is indokoló utóvérzéses eseteket jelölik

$\mathrm{LMWH}=$ alacsony molekulasúlyú heparin $; \mathrm{NOAC}=$ új típusú orális antikoaguláns; TAG „egyszeres” = egyszeres thrombocytaaggregáció-gátlás; TAG „kettős” = kettős thrombocytaaggregáció-gátlás; VKA = K-vitamin-antagonista

minor ellátást igényelt $(13 / 86=15,1 \%)$. Az ügyeleti esetek legtöbbje major kategóriába volt sorolandó $(67 / 86=77,9 \%$; lokális érzéstelenítés, kiterjedt, illetve mobilis alvadék eltávolítása, vérzéscsillapító szivacs behelyezése, sutura és tranexámsavas öblögetés, illetve két esetben szövetragasztás is), azonban hat esetben (6/86 $=7 \%$ ) osztályos felvétel is történt (a lokális vérzéscsillapításon felül volumenpótlás, transzfúzió, hematológiai konzultáció) (2.ábra). A gyógyszert nem szedő és szisztémás betegségről nem tudó pácienseknél a traumás fogeltávolítás (rupturált gingiva, frakturált és nem komprimált alveolusok) sok esetben megfigyelhető volt.

$\mathrm{Az}$ ügyeletben jelentkező véralvadásgátolt betegcsoportban, az ajánlás ellenére, mindössze egy alkalommal volt az extrakció helye suturázva(!), tranexámsavas öblögetés szükségességérôl egyikük sem hallott bevallásuk szerint, illetve gézlapok beszerzését sem javasolta a fogorvos esetleges utóvérzés esetére.

\section{Megbeszélés}

A szakmai ajánlás szerzói és az azt ismerő általános orvoskollégák (háziorvosok, belgyógyászok, kardiológusok) is sok esetben tapasztalják, hogy a berögzült fogorvosi betegellátó mechanizmusokat nehéz módosítani. A szkeptikus fogorvosok - szakmai fórumok tapasztalatai szerint - a megnövekedett utóvérzési esélytől tartanak leginkább. Nagyon fontos megemlíteni, hogy nem a fogorvosok naprakész ismereteinek hiánya (a szerzók tapasztalata szerint legalábbis), hanem a lokális vérzéscsillapítás anyag- és sokkal inkább költségigénye a korlátozó tényezô nagy valószínúséggel, hiszen a jelen társadalombiztosítási finanszírozás mellett sok esetben veszteséges a fogorvosi beavatkozás. Ezzel egy időben viszont a támogatott LMWH-terápia nagyságrenddel nagyobb költséget jelent a társadalombiztosításnak, nem is beszélve a sokszor elkerülheto, átállítás miatti általános orvosi (háziorvosi és speciális szakellátói) konzultációs megjelenésekről!

A fogorvosnál jelentkező páciensek INR-ben kifejezett optimális terápiás tartományai egyébként a mútéteket követő profilaxis esetén: $2-2,5$; mélyvénás thrombosis, pulmonalis embolia, pitvarfibrilláció fennállásakor: 2,0-3,0; és mechanikus múbillentyú, rekurráló pulmonalis embolia, foszfolipidellenes antitest szindróma esetén: 3,0-4,0 értékekkel jellemezhető $[6,8,9]$.

Megjegyzendő, hogy az esetek körülbelül 30\%-ában a mért INR-érték nem érte el a terápiás tartomány alsó határát! Az, hogy ez a páciens étrendjének, önkényes gyógyszeradag-módosításának köszönhető, nem vizsgáltuk.

Mind a fejlett nyugat-európai országok, mind az Amerikai Egyesült Államok protokolljai az antikoaguláns kezelésben részesült betegeknél - minimális eltéréssel a mért INR-érték függvényében - egyértelmú összhangban vannak, amely szerint 2,0-4,0 értékekig a gyógyszerszedést folytatva, átállítás nélkül kell a szükséges fogorvosi/szájsebészeti beavatkozást elvégezni, hangsúlyozva a megfelelő sebelláást, lokális vérzéscsillapító módszerek alkalmazását [2 , 3, 6, 10-12]. A minimálisan szükséges rutin fogorvosi vérzéscsillapító ellátás lépéseit a 3. ábrán mutatjuk be.

2009-ben megjelent szisztematikus, irodalomelemző tanulmány szerint nincs fokozott posztoperatív vérzésveszély a 2,0-3,0 INR-tartományba beállított VKA-szedő pácienseknél, amennyiben nem állítjuk le a gyógyszerszedésüket [13]. Weltman és mtsai 2015-ben közölt cikkükben szintén arra a következtetésre jutottak, hogy a 3,0-as INR-érték alatt elvégzett beavatkozásoknak nincs fokozott utóvérzésveszélye [14].

Wabl és mtsai 2015-ben készítettek egy irodalomelemzést, amely több mint 5000, antikoagulációs terápiában részesülő betegnél (INR 2,0-3,5) elvégzett közel 12 000, vérzéssel járó fogorvosi/szájsebészeti beavatkozást vizsgáltak. Az elemzés célja volt, hogy bemutassák, milyen előfordulási valószínúsége van a nem átállított (tehát VKA-hatás alatt álló) betegcsoportban a posztoperatív vérzésnek, illetve, hogy a VKA antikoagulációs terápia felfüggesztésekor milyen arányban lép fel valamilyen thrombemboliás esemény. Eredményeik alapján a betegek több mint 99,4\%-ánál nem volt olyan fokú utóvérzéssel járó komplikáció, amit helyi vérzéscsillapító módszerekkel ne lehetett volna megoldani. Elgondolkodtató viszont, hogy a 2673 páciensnél, akiknél csökkentették vagy teljesen leállították az antikoaguláns kezelést, 22 esetben $(0,8 \%)$ thromboemboliás komplikáció lépett fel, amelyből 6 eset, sajnos, végzetesnek bizonyult $(0,2 \%)[6]$.

Napeñas és mtsai egy 2013-ban megjelenő elemzésükben nem találtak szignifikáns különbséget az úgynevezett „single”, illetve „dual” thrombocytaaggregációs 


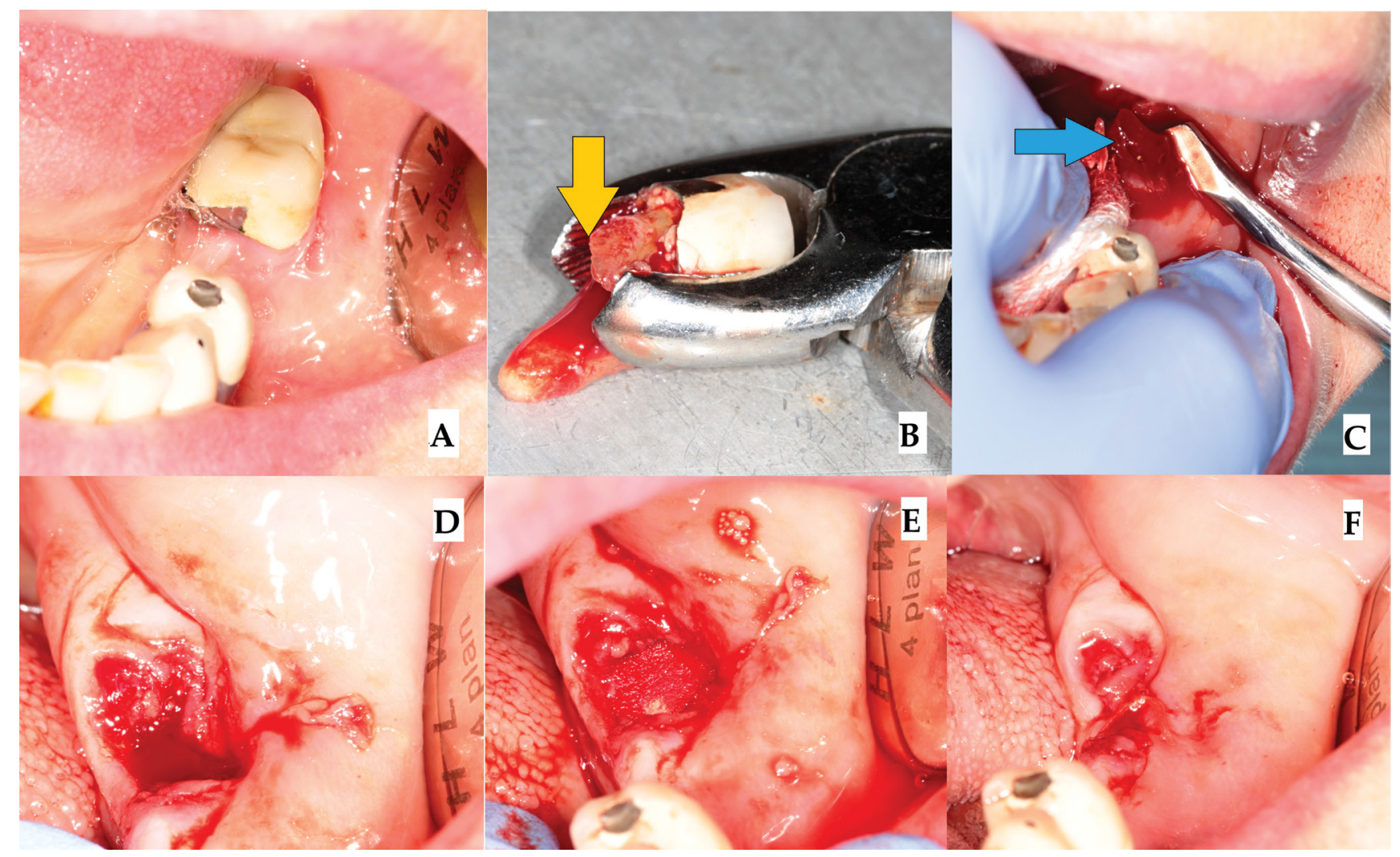

3. ábra

A hazai ajánlás alapján elvégzett extrakció folyamata. A) A bal alsó második őrlőfog eltávolítását a koronaszélek alatti mély szekunder carieses folyamat indokolta. B) A fogóval történő eltávolítás során a mesialis gyökér fracturált (sárga nyíl). C) Barry-emelővel a mesialis gyökérfragmentumot kiemeltük (kék nyíl). D) A fogeltávolítás után látható a "tátongó” extrakciós seb. E) A kollagénszivaccsal kitöltött extrakciós seb. F) Felszívódó suturával, horizontális kereszt matracöltéssel megkisebbített sebfelszín. Figyelemre méltó, hogy már a folyamat befejeztével sem látható vérzés, véres sebszivárgás. Az adott páciens INR-értéke 2,7 volt

kezelésben részesült betegeknél az utóvérzések tekintetében, ha felfüggesztették a gyógyszerszedést, illetve ha nem [15]. Bajkin és mtsai 2015-ben közölt cikkükben 160, úgynevezett „single”, illetve „dual” TAG-kezelésben részesült betegnél végeztek mindösszesen 342 fogeltávolítást. A kontrollcsoportba 105 páciens tartozott, páciensenként egy extrakciós beavatkozással. Eredményeik alapján nem találtak szignifikáns különbséget a posztoperatív vérzések tekintetében a mono-, illetve kombinált TAG-kezelésben részesülő betegek és az egészséges kontrollcsoport között [3].

Az úgynevezett új típusú antikoaguláns gyógyszereket szedő páciensek fogászati beavatkozásainak vérzéses kockázatairól még viszonylag kevés tanulmány található az irodalomban. Általánosságban elmondható, hogy a leggyakoribb fogorvosi/szájsebészeti kezelések elött nem szükséges a gyógyszerszedést módosítani [16-23].

Végignézve a nyugat-európai országok (Ausztria, Egyesült Királyság, Franciaország, Hollandia, Németország), illetve az Amerikai Egyesült Államok irányelveit a véralvadásgátló kezelésben részesülő betegek szájsebészeti kezelésével kapcsolatosan, kivétel nélkül a következő protokollokat találjuk:
1. VKA: terápiás tartományba beállított INR-értékeknél (2-4) nem szükséges sem felfüggeszteni, sem átállítani.

2. „Single”, illetve „dual” TAG: nem szükséges a gyógyszer elhagyása.

3. NOAC-szedóknél: nem szükséges a gyógyszer felfüggesztése [24-32].

A véralvadásgátló gyógyszerek módosítását annál is inkább célszerü elkerülni, hogy Magyarországon a közvetlen halálok akár 10,8\%-ban a tüdőembólia [33], míg a halálokok akár 50\%-ért (46,4\% 2012-ben) a keringési rendszer betegségei felelősek $[8,34]$.

Szomorú tény, hogy az ügyeletben utóvérzéses problémával érkező páciensek kevesebb mint $2 \%$-a kapott korrekt lokális vérzéscsillapítást a fogorvosi ellátás során (kollagén-, illetve oxidáltcellulóz-szivacs és sutura). Fontos megérteni, hogy az átállított (úgynevezett „VKALMWH bridging") páciensek ugyanúgy igénylik a korrekt és költséges helyi vérzéscsillapítási lépéseket, amint az az eredményekból is kitúnik, és ráadásul nagyobb esélyük van - irodalmi adatok tükrében - a thromboemboliás szövődményekre $[35,36]$ ! 
Anyagi támogatás: A közlemény megírása anyagi támogatásban nem részesült.

Szerzői munkamegosztás: L. D., S. N., V. L.: Retrospektív adatgyújtés. Sz. J., J.-F. Á., O. L.: A vizsgálat kidolgozása, felügyelete. L. D., Sz. J: A kézirat szövegezése. A cikk végleges változatát valamennyi szerző elolvasta és jóváhagyta.

Érdekeltségek: A szerzőknek nincsenek érdekeltségeik.

\section{Irodalom}

[1] Joób-Fancsaly, Á., Barabás, J. B., Horváth, C., et al.: Current issues of anticoagulation therapy in the course of dental treatment and oral surgery. [Véralvadásgátló gyógyszerek alkalmazásának aktuális kérdései a fogorvosi és szájsebészeti kezelések során.] Fogorv. Sz., 2008, 101(4), 147-153. [Hungarian]

[2] Bajkin, B. V., Selaković, S. D., Mirković, S. M., et al.: Comparison of efficacy of local hemostatic modalities in anticoagulated patients undergoing tooth extractions. Vojnosanit. Pregl., 2014, 71(12), 1097-1101.

[3] Bajkin, B. V., Vujkov, S. B., Milekic, B. R., et al.: Risk factors for bleeding after oral surgery in patients who continued using oral anticoagulant therapy. J. Am. Dent. Assoc., 2015, 146(6), 375381

[4] Clemm, R., Neukam, F. W., Rusche, B., et al.: Management of anticoagulated patients in implant therapy: a clinical comparative study. Clin. Oral Implants Res., 2015 Nov 23. doi: 10.1111/ clr.12732. [Epub ahead of print]

[5] Kachelmann, S., Lörincz, Á., Joób-Fancsaly, Á.: A clinical study of dental surgery in antico-agulated patients. [Antikoaguláns kezelésben részesülő betegek szájsebészeti ellááának klinikai vizsgálata.] Fogorv. Sz., 2012, 105(2), 53-58. [Hungarian]

[6] Wabl, M. J., Pinto, A., Kilham, J., et al.: Dental surgery in anticoagulated patients - stop the interruption. Oral Surg. Oral Med. Oral Pathol. Oral Radiol., 2015, 119(2), 136-157.

[7] Szalma, J., Joób-Fancsaly, Á., Hungarian Association of Oral and Maxillofacial Surgeons, Dental Implantology Association of Hungarian Dentists: Dental management of hemorrhage-prone patients. [A vérzékeny betegek fogorvosi ellátása.] Fogorv. Sz., 2015, 108(2), 57-60. [Hungarian]

[8] Hungarian Society of Thrombosis and Hemostasis, Professional Board of Transfusion and Hematology: Thromboembolism - risk, prevention and therapy. Practice Guideline. [Magyar Thrombosis és Haemostasis Társaság, Transzfuziológiai és Haematológiai Szakmai Kollégium: A thromboembolia kockázatának csökkentése és kezelése.] Orv. Hetil. 2009, 150(52), 2335-2404. [Hungarian]

[9] Nyirkos, P.: Per os anticoagulant treatment. Evidence-based medicine guidelines. [Per os anticoaguláns kezelés. Tényeken alapuló orvostudomány módszertani ajánlások.] Melania Kiadó, Budapest, 2005. [Hungarian]

[10] Sadeghi-Ghahrody, M., Yousefi-Malekshah, S. H., Karimi-Sari, H., et al.: Bleeding after tooth extraction in patients taking aspirin and clopidogrel $\left(\right.$ Plavix $\left.^{\circledR}\right)$ compared with healthy controls. Br. J. Oral Maxillofac. Surg., 2016, 54(5), 568-572.

[11] Lu, S. Y., Tsai, C. Y., Lin, L. H., et al.: Dental extraction without stopping single or dual antiplatelet therapy: results of a retrospective cohort study. Int. J. Oral Maxillofac. Surg., 2016, 45(10), 1293-1298.

[12] Bajkin, B. V., Urosevic, I. M., Stankov, K. M., et al.: Dental extractions and risk of bleeding in patients taking single and dual antiplatelet treatment. Br. J. Oral Maxillofac. Surg., 2015, 53(1), $39-43$.

[13] Nematullah, A., Alabousi, A., Blanas, N., et al.: Dental surgery for patients on anticoagulant therapy with warfarin: a systematic review and meta-analysis. J. Can. Dent. Assoc., 2009, 75(1), $41-51$.

[14] Weltman, N. J., Al-Attar, Y., Cheung, J., et al.: Management of dental extractions in patients taking warfarin as anticoagulant treatment: A systematic review. J. Can. Dent. Assoc., 2015, 81, f20-f39.

[15] Napeñas, J. J., Oost, F. C., DeGroot, A., et al.: Review of postoperative bleeding risk in dental patients on antiplatelet therapy. Oral Surg. Oral Med. Oral Pathol. Oral Radiol., 2013, 115(4), 491-499.

[16] Tsolka, P.: Dental procedures in patients with atrial fibrillation and new oral anticoagulants. Arrhythm. Electrophysiol. Rev., $2014,3(2), 85-89$.

[17] Heidbuchel, H., Verbamme, P., Alings, M., et al.: European Heart Rhythm Association practical guide on the use of new oral anticoagulants in patients with non-valvular atrial fibrillation. Europace, 2013, 15(5), 625-651.

[18] Van Diermen, D. E., van der Waal, I., Hoogstraten, J.: Management recommendations for invasive dental treatment in patients using oral antithrombotic medication, including novel oral anticoagulants. Oral Surg. Oral Med. Oral Pathol. Oral Radiol., 2013, 116(6), 709-716.

[19] Samama, M. M., Martinoli, J. L., LeFlem, L., et al.: Assessment of laboratory assays to measure rivaroxaban - an oral, direct factor Xa inhibitor. Thromb. Haemost., 2010, 103(4), 815-825.

[20] Ruff, C. T., Giugliano, R. P., Braunwald, E., et al.: Comparison of the efficacy and safety of new oral anticoagulants with warfarin in patients with atrial fibrillation: a meta-analysis of randomised trials. Lancet, 2014, 383(9921), 955-962.

[21] Beyer-Westendorf, J., Gelbricht, V., Förster, K., et al.: Peri-interventional management of novel oral anticoagulants in daily care: results from the prospective Dresden NOAC registry. Eur. Heart J., 2014, 35(28), 1888-1896.

[22] Borbola, J., Borbola, K.: Dental interventions in patients with atrial fibrillation who are on oral anticoagulant drugs. [Fogászati beavatkozások új orális antikoaguláns gyógyszereket szedő, pitvarfibrilláló betegeken.] Magyar Fogorvos, 2015, 24(2), 82-90. [Hungarian]

[23] Siller-Matula, J. M., Krumphuber, J., Jilma, B.: Pharmacokinetic, pharmacodynamic and clinical profile of novel antiplatelet drugs targeting vascular diseases. Br. J. Pharmacol., 2010, 159(3), 502-517.

[24] Van Diermen, D. E., Aartman, I. H., Baart, J. A., et al.: Dental management of patients using antithrombotic drugs: critical appraisal of existing guidelines. Oral Surg. Oral Med. Oral Pathol. Oral Radiol. Endod., 2009, 107(5), 616-624.

[25] Thean, D., Alberghini, M.: Anticoagulant therapy and its impact on dental patients: a re-view. Aust. Dent. J., 2016, 61(2), 149156.

[26] Armstrong, M. J., Gronseth, G., Anderson, D. C., et al.: Summary of evidence-based guideline: periprocedural management of antithrombotic medications in patients with ischemic cerebrovascular disease: report of the Guideline Development Subcommittee of the American Academy of Neurology. Neurology, 2013, $80(22), 2065-2069$.

[27] Douketis, J. D., Spyropoulos, A. C., Spencer, F. A., et al.: Perioperative management of antithrombotic therapy: Antithrombotic therapy and prevention of thrombosis, 9th ed.: American College of Chest Physicians Evidence-Based Clinical Practice Guidelines. Chest, 2012, 141(2 Suppl.), e326S-e350S.

[28] Peisker, A., Raschke, G. F., Schultze-Mosgau, S.: Management of dental extraction in patients with Haemophilia A and B: a report of 58 extractions. Med. Oral Patol. Oral Cir. Bucal, 2014, 19(1), e55-e60.

[29] Guideline of Academisch Centrum Tandheelkunde Amsterdam. http://www.acta-zorgnet.nl/knmt/richtlijnen/richtlijn-antistolling.pdf 
[30] Zahnärztliche Chirurgie bei Patienten mit Antikoagulanzientherapie. http://www.dgzmk.de/uploads/tx_szdgzmkdocuments/Zahnaerztliche_Chirurgie_bei_Patienten_mit_Antikoagulanzientherapie.pdf

[31] Perry, D. J., Noakes, T. J., Helliwell, P. S., et al.: Guidelines for the management of patients on oral anticoagulants requiring dental surgery. Br. Dent. J., 2007, 203(7), 389-393.

[32] British Committee for Standards in Haematology: Guidelines for the management of patients on oral anticoagulants requiring dental surgery. http://www.bcshguidelines.com/documents/ WarfarinandentalSurgery_bjh_264_2007.pdf

[33] Battyáni, I., Dósa, E., Harmat, Z.: Interventional radiological treatment of extensive pulmonary embolism and thromboembolic diseases. [Masszív pulmonalis embolia és thromboemboliás kórképek intervenciós radiológiai kezelése.] Orv. Hetil., 2015, 156(17), 674-679. [Hungarian]
[34] Hungarian Central Statistical Office: Changes in structure of death causes in Hungary, 2000-2012. [Központi Statisztikai Hivatal: A haláloki struktúra változása Magyarországon, 20002012.] https://www.ksh.hu/docs/hun/xftp/idoszaki/pdf/ halalokistruk.pdf [Hungarian]

[35] Svensson, R., Hallmer, F., Englesson, C. S., et al.: Treatment with local hemostatic agents and primary closure after tooth extraction in warfarin treated patients. Swed. Dent. J., 2013, 37(2), 71-77.

[36] Broekema, F. I., van Minnen, B., Jansma, J., et al.: Risk of bleeding after dentoalveolar surgery in patients taking anticoagulants. Br. J. Oral Maxillofac. Surg., 2014, 52(3), el5-e19.

(Szalma József dr., Pécs, Dischka Győző u. 5., 7621 e-mail: szalma.jozsef@pte.hu)

\section{$\triangle$ DEKRA}

Alapozza meg szakmai karrierjét Svájcban! Kiváló lehetőség

orvosok számára!

Svájci kórházakba, klinikákra keresünk szakorvosokat (belgyógyász, aneszteziológus, stb.) tárgyalási szintű német/angol nyelvtudással. Vezetői munkakörbe is, kiemelt bérezéssel.

Érdeklődés esetén lehetőség, várjuk önéletrajzát.

dekra@dekra-arbeit.hu 